59. Sheldon, W.: Congenital pancreatic lipase deficiency. Arch. Dis. Child., 39: 268 (1964).

60. Shenai, P. J., Reynolds, J. W., and Babson, S. G.: Nutritional balance studies in very low birth weight infants: Enhanced nutrient retention rates by an experimental formula. Pediatrics, 66: 233 (1980).

61. Skude, G. and Ihse, I.: Salivary amylase in duodenal aspirates. Scand. J. Gastroenterol., VII: 17 (1976).

62. Small, D. M.: A classification of biologic lipids based upon their interaction in aqueous systems. J. Am. Oil Chem. Soc., 45: 108. (1968).

63. Staggers, J. E., Fernando-WarnaKulasuriya, G. J. P., and Wells, M. A.: Studies on fat digestion, absorption and transport in the suckling rat. II. Triacylglycerols: molecular species, stereospecific analysis and specificity of hydrolysis by lingual lipase. J. Lipid Res., 22: 675 (1981).

64. Taylor, W. H.: Studies on gastric proteolysis. Biochem. J., 71: 73 (1959).

65. Tiruppathi, C. and Balasubramanian, K. A.: Purification and properties of an acid lipase from human gastric juice. Biochim. Biophys. Acta, 712: 692 (1982).

66. Volhard, F.: Über das fettspaltende Ferment des Magens. Z. Clin. Med., 42. 414 (1901).
67. von Ebner, V.: Cited in v. Koelliker's Handb. d. Geweb-lehre d. Menscheu. Vol. 3 p. 18.: Die acinosen Drusen der Zunge und ihrre Beziehungen zu den Geschmacks-Organen-(Leuschner and Lubensky, Graz, Austria, 1899).

68. Watkins, J. B., Szczpanik, P., Ingall, D., Klein, D. P., and Lester, R.: Bile salt metabolism in the newborn infant. Measurement of pool size and synthesis by stable isotopic techniques. N. Engl. J. Med., 288: 431 (1973).

69. Zoppi, G., Andreotti, G., Pajno-Ferrara, F., Njai, D. M., and Gaburro, D. Exocrine pancreatic function in premature and full-term neonates. Pediatr. Res., 6: 880 (1972).

70. This study was supported by National Institutes of Health Grants AM-26641 and HD-10823, and by a grant from the Mead Johnson Company. We thank Dr. J. W. Scanlon and Mrs. K. B. Scanlon for the supply of gastric aspirates from newborn infants, and Ms. Marguerite Starry for secretarial help.

71. Requests for reprints should be addressed to: Dr. Margit Hamosh; Department of Pediatrics, Georgetown University Medical Center, 3800 Reservoir Road, N.W. Washington, DC 20007.

72. Received for publication March 8, 1983

73. Accepted for publication June $20,1983$.

\title{
Longitudinal Studies on Metabolic Rate, Heat Loss, and Energy Cost of Growth in Low Birth Weight Infants
}

\author{
P. J. J. SAUER, ${ }^{(34)}$ H. J. DANE, AND H. K. A. VISSER \\ Department of Pediatrics, Erasmus University and Academic Hospital Rotterdam/Sophia Children's Hospital \\ Department of Applied Physics, Delft University of Technology, Delft, The Netherlands
}

\section{Summary}

Longitudinal studies on total and resting metabolic rate and total heat loss were made in $14 \mathrm{LBW}$ infants, age 1-58 d. Metabolic rate was calculated from indirect calorimetry, heat loss was measured by direct calorimetry. Total metabolic rate and total heat loss were lowest during the first week of life, 178.9 \pm 18.0 and $171.8 \pm 15.5 \mathrm{~kJ} \cdot \mathrm{kg}^{-1} \cdot 24 \mathrm{~h}^{-1}$, respectively. During the age period of 8-58 d both total metabolic rate and heat loss showed a very slight increase with age: mean total metabolic rate was $278.8 \pm 2.6$ and mean total heat loss $257.0 \pm 3.4 \mathrm{~kJ} \cdot \mathrm{kg}^{-1}$. $24 \mathrm{~h}^{-1}$. Resting metabolic rate was $171.0 \pm 25.2 \mathrm{~kJ} \cdot \mathrm{kg}^{-1} \cdot 24 \mathrm{~h}^{-1}$ during the first week of life and 248.0 \pm 2.5 during $\mathrm{d} 8-58$.

The energy cost of components of new tissue was calculated from the energy balance equation. $E_{\text {components }}$ during the second week of life was $25.5 \pm 4.9 \mathrm{~kJ} / \mathrm{g}$ weight gain and $11.9 \pm 0.4 \mathrm{~kJ} /$ $\mathrm{g}$ weight gain over subsequent weeks. The net energy cost of tissue synthesis, calculated from the difference between indirect and direct calorimetry was $3.2 \pm 1.1 \mathrm{~kJ} / \mathrm{g}$ weight gain during the second week and $1.1 \pm 0.1 \mathrm{~kJ} / \mathrm{g}$ weight gain in the following weeks. A neonate who receives a caloric intake of $535 \mathrm{~kJ} \cdot \mathrm{kg}^{-1}$. $24 \mathrm{~h}^{-1}$ and is growing at a rate of $17 \mathrm{~g} \cdot \mathrm{kg}^{-1} \cdot 24 \mathrm{~h}^{-1}$ will use $42 \%$ of the caloric intake for maintenance and thermoregulation, $6 \%$ for activity, $38 \%$ for the components of new tissue, $\mathbf{4 \%}$ for tissue synthesis and $10 \%$ for loss in faeces and urine.

\section{Abbreviations}

BWT, birth weight

GA, gestational age

LBW, low birth weight

VLBW, very low birth weight
The prognosis for survival of VLBW infants is improving (30). The quality of outcome will depend on adequate growth and caloric intake during the critical postnatal period of development as well as on adequate circulatory and ventilatory support. Studies concerning caloric intake and growth in VLBW infants are therefore necessary. The energy balance equation makes it possible to calculate the energy cost of growth and to give guidelines for the caloric intake of these infants $(6,8,11,20,24)$.

The energy balance equation has been defined as $(24,27)$ :

$$
\text { Energy }_{\text {intake }}=\text { Energy }_{\text {excreted }}+\text { Energy }_{\text {expended }}+\text { Energy }_{\text {components }}
$$

Energy $_{\text {intake }}$ represents the energy in the food. Energy excreted $_{\text {Occurs }}$ mainly via the faeces in the postnatal period. Energy $y_{\text {expended }}$ includes 1 ) the energy used in maintenance, 2) the energy used for thermoregulation, 3) the energy used in activity, and 4) the energy used for the synthesis of new tissue. Energy expended is equal to the metabolic rate and can be measured by indirect calori-

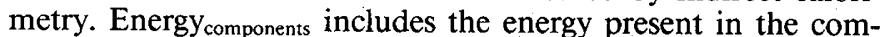

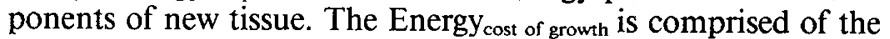
energy required for the synthesis of new tissue and the energy stored in the components of this new tissue:

$$
\text { Energy }_{\text {cost of growth }}=\text { Energy }_{\text {components }}+\text { Energy }_{\text {synthesis. }}
$$

The cost of tissue synthesis represents energy required for the organisation of the components of new tissue $(6,9,27,29)$ and for the formation of complex proteins, lipids, carbohydrates, and combinations thereof $(14,15)$. All energy used for maintenance, thermoregulation, and activity is given off as heat. Part of the energy consumed for tissue synthesis is converted to heat and given off. Another part of the energy for tissue synthesis is not 


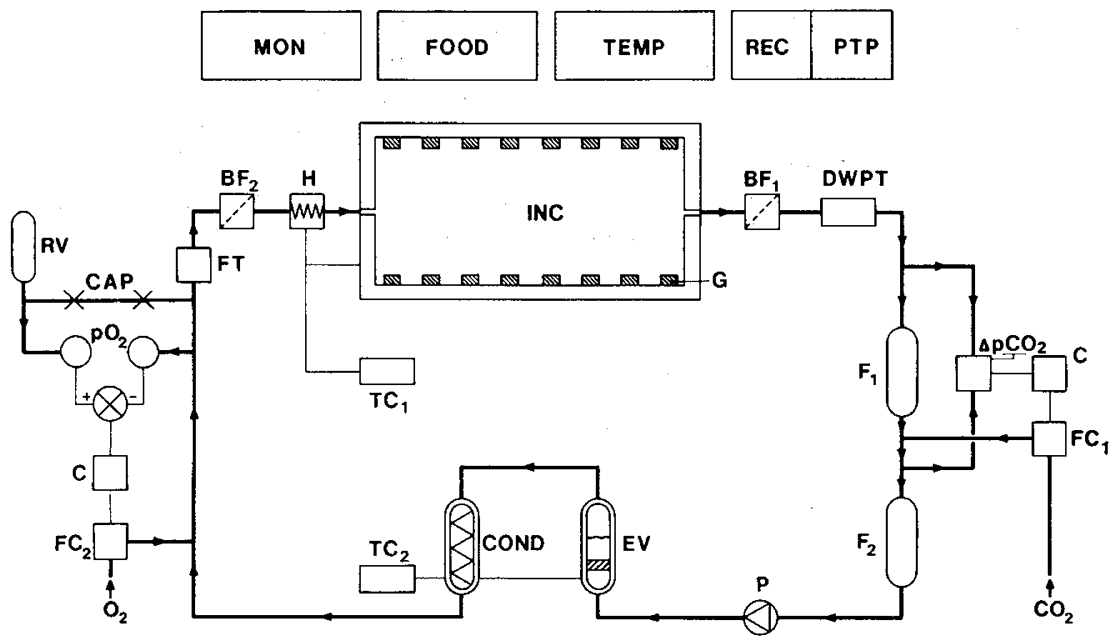

Fig. 1. Schematic diagram of the calorimeter. Abbreviations: INC, incubator; G, gradient layer; BF, bacterial filter; DWPT, dewpoint hygrometer; $\mathbf{F}_{1}$ and $\mathbf{F}_{2}, \mathrm{CO}_{2}$ absorbers; $\triangle \mathbf{P C O}_{2}, \mathrm{CO}_{2}$ partial pressure difference sensor; $\mathbf{C}$, electronical controller; $\mathrm{FC}_{\mathbf{1}}$, flow controller $\mathrm{CO}_{2} ; \mathbf{P}$, main circuit pump; EV, bubble chamber; COND, condensor; $\mathbf{T C}_{2}$, temperature controller of condensor and bubble chamber; $\mathbf{F C} \mathbf{C}_{2}$, flow controller $\mathrm{O}_{2} ; \mathbf{P O}_{2}, \mathrm{O}_{2}$ partial pressure sensors; RV, reference vessel;.CAP, capillary; FT, main circuit flow sensor; $\mathbf{H}$, heat exchanger; $\mathbf{T C}_{\mathbf{l}}$, temperature controller of incubator and heat exchanger; MON, heart beat and apnea monitor; FOOD, feeding system; TEMP, thermometer system; REC, recorder; and PTP, papertape puncher.

Table 1. Clinical details of the patients*

\begin{tabular}{|c|c|c|c|c|c|c|}
\hline \multirow[b]{2}{*}{$\mathrm{N}$} & \multirow[b]{2}{*}{ BWT } & \multirow[b]{2}{*}{$\mathrm{GA}$} & \multicolumn{2}{|c|}{ Period of study } & \multirow{2}{*}{$\begin{array}{c}\begin{array}{c}\text { Number } \\
\text { of }\end{array} \\
\text { measurements }\end{array}$} & \multirow{2}{*}{$\begin{array}{c}\text { Complications } \\
\text { before } \\
\text { measurements }\end{array}$} \\
\hline & & & $\begin{array}{l}\text { p.n.a. } \\
\text { (d) }\end{array}$ & $\begin{array}{c}\text { weight } \\
\text { (g) }\end{array}$ & & \\
\hline 1 & 920 & 29 & $8-58$ & $870-2050$ & 7 & P.D.A. \\
\hline 2 & 1400 & 30 & $31-45$ & $1460-1987$ & 5 & R.D.S. P.D.A. \\
\hline 3 & 1320 & 30 & $24-45$ & $1325-2110$ & 6 & R.D.S. \\
\hline 4 & 1150 & 30 & $14-50$ & $1120-2055$ & 5 & R.D.S. \\
\hline 5 & 985 & 31 & $30-49$ & $1420-1870$ & 3 & R.D.S. \\
\hline 6 & 1300 & 31 & $6-34$ & $1020-1590$ & 3 & R.D.S. \\
\hline 7 & 1190 & 32 & $11-38$ & $1115-1640$ & 3 & $\ldots$ \\
\hline 8 & 940 & 32 & $20-43$ & $938-1500$ & 5 & septicaemia \\
\hline 9 & 1270 & 33 & $9-35$ & $1230-1845$ & 4 & $\ldots$ \\
\hline 10 & 1750 & 33 & $1-8$ & $1750-1680$ & 2 & $\ldots$ \\
\hline 11 & 1850 & 33 & $3-29$ & $1760-1475$ & 2 & N.E.C. \\
\hline 12 & 1280 & 33 & $23-37$ & $1500-1940$ & 4 & $\ldots$ \\
\hline 13 & 1370 & 33 & $9-30$ & $1350-2050$ & 6 & $\ldots$ \\
\hline 14 & 1460 & 35 & $15-21$ & $1580-1770$ & 2 & $\ldots$ \\
\hline
\end{tabular}

* Abbreviations: BWT, birth weight; GA, gestational age; p.n.a., postnatal age; P.D.A., patent ductus arteriosus; R.D.S., respiratory distress syndrome; and N.E.C., necrotizing enterocolitis.

Table 2. Composition of Nenatal (Nutricia) per $100 \mathrm{ml}$ formula

\begin{tabular}{lc} 
Milk fat & $0.1 \mathrm{~g}$ \\
Vegetable fat & \\
Maize oil & $2.6 \mathrm{~g}$ \\
MCT & $1.8 \mathrm{~g}$ \\
Protein & \\
$\quad$ Whey-protein & $1.1 \mathrm{~g}$ \\
Casein & $0.7 \mathrm{~g}$ \\
Lactose & $2.4 \mathrm{~g}$ \\
Glucose & $2.2 \mathrm{~g}$ \\
Dextrin-maltose & $2.9 \mathrm{~g}$ \\
Minerals & $0.4 \mathrm{~g}$ \\
$\mathrm{~kJ}$ & 315 \\
\hline
\end{tabular}

given off as heat but stored in new tissues, for instance in high energy phosphate bonds, together with the energy of the components. Therefore the net energy of tissue synthesis, is equal to the difference between the energy expenditure calculated from indirect calorimetry and the heat loss calculated from direct calorimetry.

\section{MATERIALS AND METHODS}

Metabolic rate and heat loss were longitudinally measured during periods of 4-24 h (median $6 \mathrm{~h}$ ) in 14 neonates BWT, $870-1850 \mathrm{~g}$, GA $29-34$ wk until they reached $2000 \mathrm{~g}$. Age during the periods of measurements was 1-58 d and weight, 940-2110 g. Further details are given in Table 1 . We attempted to measure each infant once or twice weekly; however, due to medical and technical problems, this could not always be realized. Fifty-seven measurements were made, 2-7 measurements per infant. In 13 neonates, weight during the measurements was below -2 SD of the intrauterine growth curve (32). During the weeks in which the studies were done and during the measurements themselves, the infants received Nenatal as a continuous infusion into the stomach via a nasogastric tube. Nenatal is an adapted milk formula feed developed by Nutricia, Zoetermeer, (The Netherlands), for feeding the preterm baby. The composition is given in Table 2. Informed parental consent was obtained before each study.

A direct and indirect calorimeter, designed to measure the energy expenditure of babies below $2.5 \mathrm{~kg}$ was used. The calorimeter, as described earlier (24) (Fig. 1), is a closed system and 
consists of an incubator that has a double gradient layer which measures the heat loss from radiation and convection. The incubator is constructed so that heat loss through conduction is negligible. Water circulates between the double walls of the incubator and the temperature of the water can be altered rapidly and accurately. The air coming from the incubator is passed through a bacterial filter and goes into a dewpoint hygrometer where the amount of water produced is measured. Subsequently the carbon dioxide production is measured and then the $\mathrm{CO}_{2}$ is absorbed from the circulating air. The air then passes through a pump to a bubble chamber and then to a condensor so that it is brought to a dew point of $18^{\circ} \mathrm{C}$. The oxygen consumption is measured using two oxygen sensors and a reference vessel. The oxygen consumed is replaced. The air passes through a flow meter, bacterial filter, and a heater and thence back into the incubator. The accuracy of the various measurements is as follows: dry heat loss $\pm 0.1 \mathrm{~W}$; wet heat loss $\pm 0.2 \mathrm{~W}$; oxygen consumption $\pm 0.2 \mathrm{ml} / \mathrm{min}$; carbon dioxide production \pm 0.2 $\mathrm{ml} / \mathrm{min}$.

Calibration, using an alcohol flame, gave a maximum difference between direct and indirect calorimetry of $10 \mathrm{~kJ} / 24 \mathrm{~h}$. During the measurements, the temperature was recorded continuously at six sites on the skin and in the mid-oesophagus. Figures from the literature (13) were used as a guide for the initial temperature setting of the incubator and this was adjusted when necessary, taking into account the measured skin and oesophageal temperatures. The patients were nursed naked during the measurement with the exception of a plastic covered diaper that prevented evaporation from urine and faeces.

The formula, $\mathrm{M}=15.06 \mathrm{~V}_{\mathrm{O}_{2}}+5.04 \mathrm{~V}_{\mathrm{CO}_{2}}$ was used for the calculation of the indirect calorimetry. $\mathrm{M}$ denotes metabolic rate in $\mathrm{J} / \mathrm{min}, \mathrm{V}_{\mathrm{O}_{2}}$, oxygen consumption in $\mathrm{ml} / \mathrm{min}$; and $\mathrm{V}_{\mathrm{CO}_{2}}$, carbon dioxide production in $\mathrm{ml} / \mathrm{min}$. This formula is calculated from the caloric value and the respiratory quotient of glucose and fatty acids (average values) as present in the milk feeding used in this study. (Caloric value of oxygen used for the combination of carbohydrates $21 \mathrm{~kJ} / \mathrm{l} \mathrm{O}_{2}$ and of fatty acids $19.8 \mathrm{~kJ} / 1 \mathrm{O}_{2}$; respiratory quotient of oxidation of glucose 1.00 and of fatty acids 0.72 ).

Total metabolic rate and total heat loss were calculated from the measurements. It was assumed that the measurement period was representative of the whole day and in order to compare the results all data were calculated for $24 \mathrm{~h}$. A 6-h period is too short to be able to measure the increase in body weight due to growth accurately because of the influence of retention or passage of urine and faeces; therefore, the babies were weighed regularly 2 $\mathrm{d}$ before and after the measurement and the average weight gain was calculated. During the measurements the activity state was monitored continuously and scored according to the scores for behavioural state (19).

Metabolic rate, measured during state I (eyes closed, regular respiration, no body movements apart from occasional startles), was considered as resting metabolic rate. Resting metabolic rate, observed during $20 \mathrm{~min}$ of each measurement, was recorded. In the 16 cases that did not have state $I$, a period of $20 \mathrm{~min}$ with minimal metabolic rate was chosen to represent resting metabolic rate. During the experiments, the feeding was given continuously via a nasogastric tube.

The energy loss via faeces and urine was not measured in this study. But, in a pilot study on infants of the same weight and age group and undergoing the same feeding regime, bomb calorimetry measured faecal energy losses were less than $10 \%$ of calorie intake. It was assumed, therefore, in this study that $10 \%$ of the calorie intake was lost in the faeces and urine. Fat in Nenatal consists of a high proportion of medium chain fatty acids and unsaturated fatty acids which are well absorbed by preterm babies $(21,26,31)$.

\section{RESULTS}

Metabolic rate and heat loss. The results of the total metabolic rate, which was calculated from indirect calorimetry, and total heat loss, which was measured by direct calorimetry are given in Table 3 and Figure 2. The total metabolic rate as well as the total heat loss was lowest during the first week of life; however, only three measurements were made during this period. Total metabolic rate showed a very slight increase with age after the first week of life and averaged $278.8 \pm 2.6 \mathrm{~kJ} \cdot \mathrm{kg}^{-1} \cdot 24 \mathrm{~h}^{-1}$ (mean \pm $\mathrm{SE}$ ). Heat loss in all but one measurement was lower than the metabolic rate, heat loss after the first week of life was $257.0 \pm$ $3.4 \mathrm{~kJ} \cdot \mathrm{kg}^{-1} \cdot 24 \mathrm{~h}^{-1}$. The paired difference between metabolic

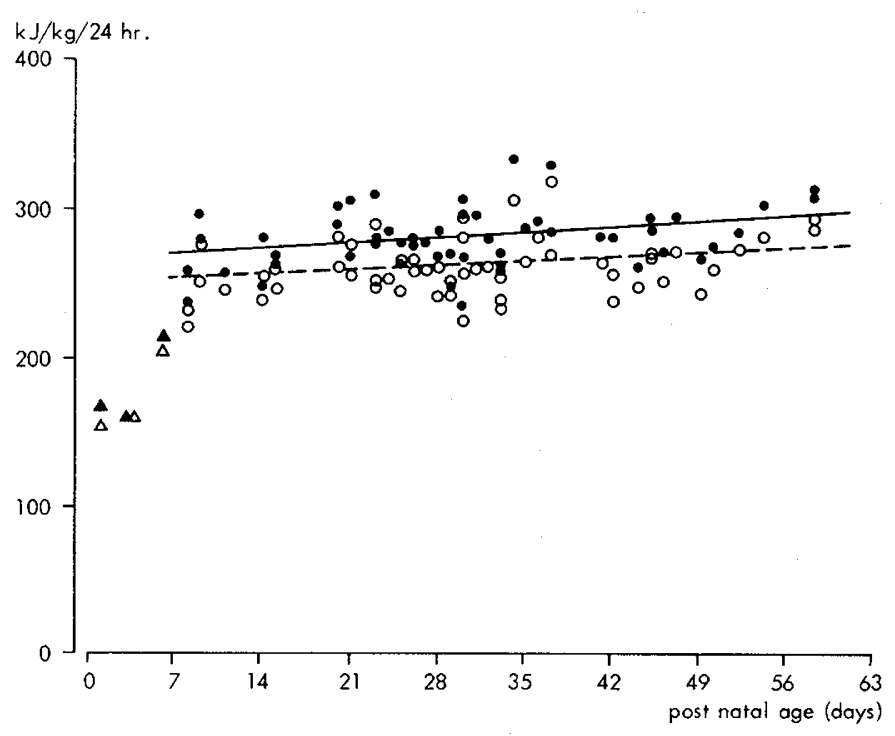

Fig. 2. Total metabolic rate and total heat loss as function of postnatal age. $\Delta$ metabolic rate, first wk; $\Delta$ heat loss, first wk; metabolic rate, after first wk; and $O$ heat loss, after first wk. After first wk $(y=a \pm b x)$ and $(n=54)$ : metabolic rate, $\mathrm{a}=269.3 \pm 7.3, \mathrm{~b}=0.4 \pm 0.2$; and heat loss, $a=250.0 \pm 6.9 ; b=0.4 \pm 0.2$. The slope of both regression lines is statistically different from zero.

Table 3. Summary of the results of the measurements

\begin{tabular}{|c|c|c|c|c|c|c|c|c|}
\hline $\begin{array}{l}\text { Age } \\
\text { (d) }\end{array}$ & $\begin{array}{c}\text { Number } \\
\text { measure- } \\
\text { ments }\end{array}$ & $\begin{array}{c}\text { Caloric intake } \\
\left(\mathrm{kJ} \cdot \mathrm{kg}^{-1} \cdot 24 \mathrm{~h}^{-1}\right)\end{array}$ & $\begin{array}{c}\text { Resting } \\
\text { metabolic rate } \\
\left(\mathrm{kJ} \cdot \mathrm{kg}^{-1} \cdot 24 \mathrm{~h}^{-1}\right)\end{array}$ & $\begin{array}{c}\text { Total metabolic } \\
\text { rate } \\
\left(\mathrm{kJ} \cdot \mathrm{kg}^{-1} \cdot 24 \mathrm{~h}^{-1}\right) \\
\end{array}$ & $\begin{array}{c}\text { Total heat } \\
\text { production } \\
\left(\mathrm{kJ} \cdot \mathrm{kg}^{-1} \cdot 24 \mathrm{~h}^{-1}\right)\end{array}$ & $\begin{array}{l}\text { Weight } \\
\text { gain } \\
\left(\mathrm{g} \cdot \mathrm{kg}^{-1} \cdot 24\right. \\
\left.\mathrm{h}^{-1}\right)\end{array}$ & $\begin{array}{c}\mathrm{E}_{\text {Components }} \\
(\mathrm{kJ} / \mathrm{g}) \\
\text { weight } \\
\text { gain }\end{array}$ & $\begin{array}{c}E_{\text {Synthesis }} \\
(\mathrm{kJ} / \mathrm{g}) \\
\text { weight } \\
\text { gain }\end{array}$ \\
\hline $1-7$ & 3 & $196.9 \pm 72.3^{*}$ & $171.0 \pm 25.2$ & $178.9 \pm 18.0$ & $171.8 \pm 15.5$ & 0 & $\cdots$ & \\
\hline $8-14$ & 7 & $537.5 \pm 16.8$ & $242.3 \pm 9.5$ & $263.6 \pm 6.8$ & $245.9 \pm 6.7$ & $10.5 \pm 1.5$ & $25.5 \pm 4.9$ & $3.2 \pm 1.1$ \\
\hline $15-21$ & 6 & $571.4 \pm 15.4$ & $247.0 \pm 8.7$ & $282.6 \pm 7.5$ & $263.7 \pm 5.2$ & $17.8 \pm 1.2$ & $12.8 \pm 1.1$ & $1.1 \pm 0.2$ \\
\hline $22-28$ & 11 & $545.5 \pm 6.5$ & $252.3 \pm 4.6$ & $276.5 \pm 4.7$ & $242.9 \pm 8.7$ & $19.0 \pm 0.9$ & $11.8 \pm 0.6$ & $1.3 \pm 0.2$ \\
\hline $29-35$ & 13 & $539.2 \pm 7.0$ & $248.5 \pm 5.0$ & $275.8 \pm 7.1$ & $259.2 \pm 6.5$ & $18.0 \pm 1.1$ & $12.3 \pm 0.8$ & $1.1 \pm 0.2$ \\
\hline $36-42$ & 6 & $558.0 \pm 13.1$ & $249.0 \pm 10.6$ & $288.0 \pm 9.3$ & $272.5 \pm 10.8$ & $17.9 \pm 0.9$ & $12.1 \pm 1.0$ & $1.1 \pm 0.2$ \\
\hline $43-58$ & 11 & $524.6 \pm 9.9$ & $246.6 \pm 4.0$ & $285.0 \pm 5.2$ & $266.0 \pm 4.9$ & $18.5 \pm 1: 3$ & $11.5 \pm 0.8$ & $1.1 \pm 0.1$ \\
\hline
\end{tabular}

${ }^{*}$ Mean \pm SEM. 
rate and heat loss was $20.5 \pm 0.8 \mathrm{~kJ} \cdot \mathrm{kg}^{-1} \cdot 24 \mathrm{~h}^{-1}$ or $7.4 \%$ of the indirect calorimetry $(p<0.001)$.

Resting metaboic rate was constant from the second week of life onwards. It was lower during the first week. The resting metabolic rate after the first week was $248.0 \pm 2.5 \mathrm{~kJ} \cdot \mathrm{kg}^{-1} \cdot 24$ $\mathrm{h}^{-1}$. Further details are given in Table 3 and Figure 3.

Energy used for activity. The only difference between the resting metabolic rate and the total metabolic rate is the activity of the infant, as both measurements were made under the same conditions. Using this method the energy used for activity was found to increase from $18 \mathrm{~kJ} \cdot \mathrm{kg}^{-1} \cdot 24 \mathrm{~h}^{-1}$ on 7 to $48 \mathrm{~kJ} \cdot \mathrm{kg}^{-1}$. $24 \mathrm{~h}^{-1}$ on $\mathrm{d} 58$. The mean energy used for activity amounted to $30.8 \mathrm{~kJ} \cdot \mathrm{kg}^{-1} \cdot 24 \mathrm{~h}^{-1}$ or $5.7 \%$ of the caloric intake.

Energy intake. We attempted to give all infants after the first week of life $175 \mathrm{ml} \cdot \mathrm{kg}^{-1} \cdot 24 \mathrm{~h}^{-1}$ Nenatal $\left(550 \mathrm{~kJ} \cdot \mathrm{kg}^{-1} \cdot 24 \mathrm{~h}^{-1}\right)$. The mean caloric intake after the first week was $543 \pm 5.0 \mathrm{~kJ}$. $\mathrm{kg}^{-1} \cdot 24 \mathrm{~h}^{-1}$. During the first days of life only glucose IV was given. Further details are given in Table 3.

Weight gain. No weight gain was observed during the first week of life. Weight gain during the second week was $10.5 \pm 1.5$ $\mathrm{g} \cdot \mathrm{kg}^{-1} \cdot 24 \mathrm{~h}^{-1}$. After the second week of life weight gain was higher, $18.7 \pm 0.5 \mathrm{~g} \cdot \mathrm{kg}^{-1} \cdot 24 \mathrm{~h}^{-1}$. Weight gain showed no increase after the second week of life.

Energy cost of components of new tissue. Using the energy balance equation $\mathrm{E}_{\text {components }}$ is calculated from each measurement. The results are given in Table 3 and Figure 4 . $E_{\text {components }}$ showed some very high results in the second week of life. After the second week the results showed no correlation with age. $\mathrm{E}_{\text {components }}$ calculated after the second week was $11.9 \pm 0.4 \mathrm{~kJ} / \mathrm{g}$ weight gain.

Net energy cost of tissue synthesis. The net energy cost of tissue synthesis is calculated from the paired difference metabolic rate and heat loss. Some high results were found during the second week of life but the results were relatively constant after the second week, $1.1 \pm 0.1 \mathrm{~kJ} / \mathrm{g}$ weight gain and showed no correlation with age.

\section{DISCUSSION}

Metabolic rate and heat loss. The metabolic rate of $\mathrm{LBW}$ infants at rest has been calculated in many studies of oxygen consumption. Many authors $(3,7,9,12,16,17,23,25,28)$ have shown that it increases slowly during the first week. It is not known if the oxygen consumption at rest increases after the age of 1 wk. Some studies $(7,12,12,28)$ show an increase, but in other studies it is found to remain constant $(9,16,23,25)$.

Longitudinal studies of total metabolic rate in VLBW infants have been reported recently $(9,18)$. An increase is found during the first weeks of life. The resting metabolic rate as well as the

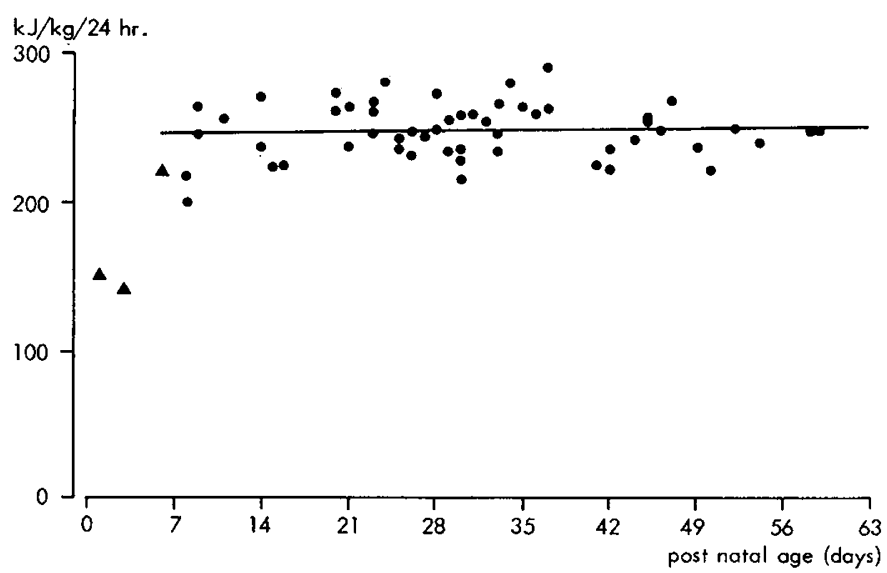

Fig. 3. Resting metabolic rate as function of postnatal age. $\Delta$ first wk and $\bullet$ after first wk. After first wk $(\mathrm{y}=\mathrm{a} \pm \mathrm{bx})$ and $(n=54): \mathrm{a}=245.9$ \pm 6.4 and $b=0.07 \pm 0.2$. The slope of the regression line is not statistically different from zero, $P<0.001$.

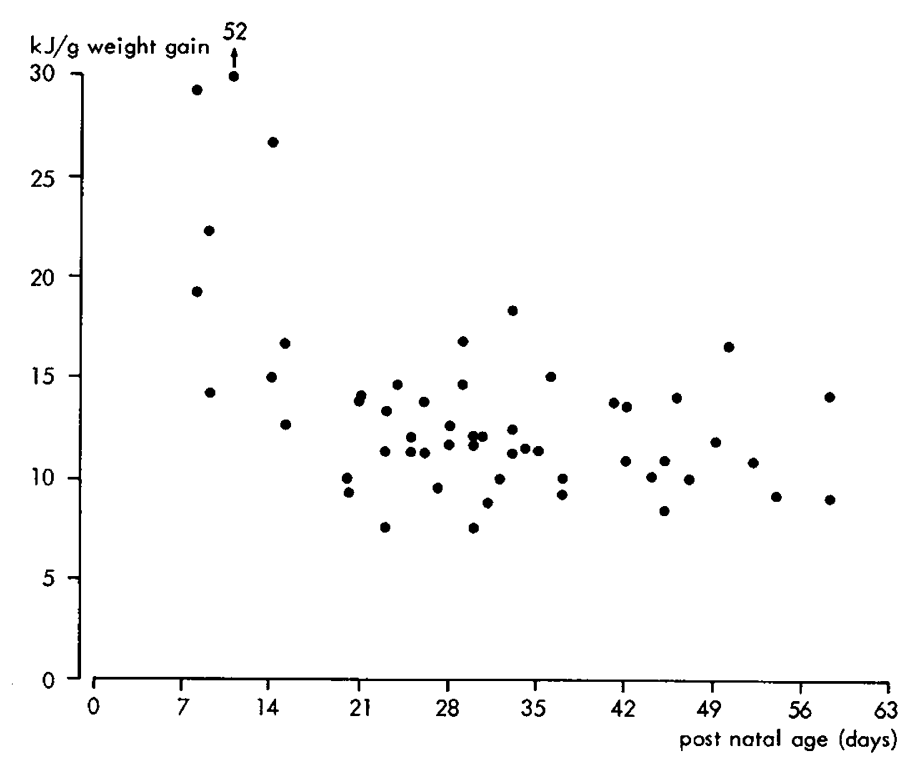

Fig. 4. Energy present in the components of new tissue as function of postnatal age.

total metabolic rate was found to be higher during the period in which neonates were growing (16-39 d) compared with the period in which neonates were not growing (2-5 d) (22).

In our studies the resting as well as the total metabolic rate was lowest during the first week of life. Thereafter, resting metabolic rate showed no increase with age but total metabolic rate showed a very small increase with age. This difference is due to the increase in activity of the infant. The lower metabolic rate observed during the first week of life may be caused by the lower caloric intake that is given during this period. It is shown that the rate of increase of oxygen consumption after birth is influenced by the amount of food that is given $(2,9,10)$. Oxygen consumption decreases during starvation and increases during recovery in malnourished infants $(2,29)$. In our study the caloric intake during the first week of life was lower compared with the following weeks. The mean caloric intake after the first week of life was $543 \mathrm{~kJ} \cdot \mathrm{kg}^{-1} \cdot 24 \mathrm{~h}^{-1}$. A resting and total metabolic rate of 248 and $278 \mathrm{~kJ} \cdot \mathrm{kg}^{-1} \cdot 24 \mathrm{~h}^{-1}$, respectively, will be normal for a growing neonate of less than $2 \mathrm{~kg}$, receiving $545 \mathrm{~kJ} \cdot \mathrm{kg}^{-1} \cdot 24$ $\mathrm{h}^{-1}$. Recently it was suggested (4) that an increase of caloric intake above $555 \mathrm{~kJ} \cdot \mathrm{kg}^{-1} \cdot 24 \mathrm{~h}^{-1}$ in LBW infants increases the metabolic rate at the expense of growth and might be at no advantage to the infants.

The resting metabolic rate includes energy used for maintenance, thermoregulation, and tissue synthesis. As our studies were performed in a thermal neutral environment, the energy for thermoregulation can be ignored. The net energy cost of tissue synthesis amounted to $20 \mathrm{~kJ} \cdot \mathrm{kg}^{-1} \cdot 24 \mathrm{~h}^{-1}$ in this study. The energy used for maintenance after the first week of life can so be calculated as $228 \mathrm{~kJ} \cdot \mathrm{kg}^{-1} \cdot 24 \mathrm{~h}^{-1}$. The energy used for activity in our study, $31 \mathrm{~kJ} \cdot \mathrm{kg}^{-1} \cdot 24 \mathrm{~h}^{-1}$, is lower than found by Brooke et al. (6), who reported $97 \mathrm{~kJ} \cdot \mathrm{kg}^{-1} \cdot 24 \mathrm{~h}^{-1}$, but somewhat higher than found by Reichman et al. (20), who reported 16.7 $\mathrm{kJ} \cdot \mathrm{kg}^{-1} \cdot 24 \mathrm{~h}^{-1}$. Two explanations for this difference can be given. The infants studied by Reichman et al. were smaller compared with the infants studied by Brooke et al. The weight of the infants in our study ranged from $870-2120 \mathrm{~g}$. The energy used for activity showed a small increase with weight and age. Also the method used by Brooke et al. is quite different from the method used in the other studies. Brooke et al. measured the oxygen consumption at different levels of activity during short periods. The proportion of time spent in activity was calculated from three 1 -h periods of observation. In the other studies, the energy used for activity is calculated from the difference between the total metabolic rate and the resting metabolic rate. 
Energy present in the components of new tissue. $\mathrm{E}_{\text {components }}$ values calculated from our studies after the second week of life are quite comparable to results published $(6,8,11)$. $\mathrm{E}_{\text {components }}$ is found to be $9.6,16.8$, and $15.2 \mathrm{~kJ} / \mathrm{g}$ weight gain in the same group of infants. The energy cost of growth in a term baby of $3900 \mathrm{~g}$ is calculated using Atkinson's metabolic price system (14, 15). For the change in body composition the reference fetus (33) is used. $E_{\text {components }}$ is calculated as $6.8 \mathrm{~kJ} / \mathrm{g}$ weight gain. $\mathrm{E}_{\text {components }}$ is also calculated from studies on infants recovering from malnutrition as $23-13.8 \mathrm{~kJ} / \mathrm{g}$ weight gain $(1,29)$. The higher energy cost of components of new tissue we found during the second week of life may be influenced by the lower weight gain observed during this period; as $\mathrm{E}_{\text {components }}$ is expressed per gram weight gain.

Growth, however, is not equal to weight gain. Weight is influenced by body water as well as by solids. The amount of body water decreases during the first weeks of life in VLBW infants. This decrease may have influenced the weight gain observed in the second week of life.

Net energy cost of synthesis of new tissue. As mentioned in the "Introduction," the net energy cost of tissue synthesis can be calculated from the difference between metabolic rate and heat production (24). Using this method, we calculated values after the second week of life that correlate well with results of other studies on $E_{\text {synthesis. }} E_{\text {synthesis }}$ is calculated from the increase in oxygen consumption observed after a feed in infants recovering from malnutrition as $1.1 \mathrm{~kJ} / \mathrm{g}$ weight gain (5). Using the same method in VLBW infants $E_{\text {synthesis }}$ is calculated as $1.7 \mathrm{~kJ} / \mathrm{g}$ weight gain (8). Using Atkinson's metabolic price system $\mathrm{E}_{\text {synthesis }}$ is calculated as 1.3 and $1.2 \mathrm{~kJ} / \mathrm{g}$ weight gain $(14,15)$.

The energy used for components of new tissue as well as the energy for synthesis showed no increase after the second week of life. From this data it can be speculated that the composition of new tissue during this period of growth is also constant.

Caloric intake. The optimal caloric intake of a VLBW infant is not known. From the results of our study however, the caloric needs of a VLBW infant may be calculated. Energy must be provided for maintenance, activity, thermoregulation, tissue synthesis, and components of new tissue. Moreover, energy loss in the faeces must be taken into account. In our study the resting metabolic rate, including energy for maintanence and thermoregulation, was an average of $228 \mathrm{~kJ} \cdot \mathrm{kg}^{-1} \cdot 24 \mathrm{~h}^{-1}$. The energy for activity amounted to $31 \mathrm{~kJ} \cdot \mathrm{kg}^{-1} \cdot 24 \mathrm{~h}^{-1}$.

The energy required for growth depends on the growth rate. The optimal weight gain is not known. Taking the "reference

$$
\text { Caloric intake } 535 \mathrm{~kJ} / \mathrm{kg} / 24 \mathrm{hr}
$$

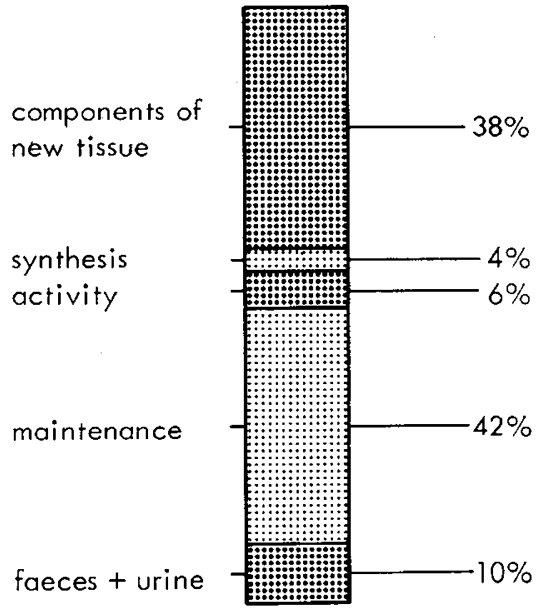

Fig. 5. Energy balance of a very low birth weight infant, body weight $1-2 \mathrm{~kg}$, growing $17 \mathrm{~g} \cdot \mathrm{kg}^{-1} \cdot 24 \mathrm{~h}^{-1}$. fetus" (33) as standard, weight gain between 1000-2000 g has to be $16 \mathrm{~g} \cdot \mathrm{kg}^{-1} \cdot 24 \mathrm{~h}^{-1}$. When a neonate is growing parallel to the intrauterine growth curves (32), weight gain between 1000-2000 will be $\pm 17 \mathrm{~g} \cdot \mathrm{kg}^{-1} \cdot 24 \mathrm{~h}^{-1}$, the energy cost of tissue synthesis will be 19 , and of components $202 \mathrm{~kJ} \cdot \mathrm{kg}^{-1} \cdot 24 \mathrm{~h}^{-1}$. Adding a caloric loss in faeces and urine of $10 \%$ of the intake, the caloric intake of a VLBW infant can be calculated as $535 \mathrm{~kJ} \cdot \mathrm{kg}^{-1} \cdot 24$ $\mathrm{h}^{-1}$.

Partition of energy utilization. The energy utilization of a VLBW infant of $1-2 \mathrm{~kg}$, receiving $535 \mathrm{~kJ} \cdot \mathrm{kg}^{-1} \cdot 24 \mathrm{~h}^{-1}$ and growing $17 \mathrm{~g} \cdot \mathrm{kg}^{-1} \cdot 24 \mathrm{~h}^{-1}$, may be divided as follows (Fig. 5): maintenance and thermoregulation 228 , activity 31 , tissue synthesis 19 , components of new tissue 202 , and losses via faeces and urine $55 \mathrm{~kJ} \cdot \mathrm{kg}^{-1} \cdot 24 \mathrm{~h}^{-1}$.

\section{REFERENCES AND NOTES}

1. Ashworth, A., Bell, R., James, W. P. T., and Waterlow, J. C.: Calorie requirements for children recovering from protein-calorie malnutrition. Lancet, 2 : 600 (1968).

2. Ashworth, A.: Growth rates in children recovering from protein-calorie malnutrition. Br. J. Nutr., 23: 835 (1969).

3. Bhakoo, O. N. and Scopes, J. W.: Minimal rates of oxygen consumption in small-for-dates babies during the first week of life. Arch. Dis. Child., 49: 583 (1974).

4. Brooke, O. G.: Energy balance and metabolic rate in preterm infants fed with standard and high energy formulas. Br. J. Nutr., 44: 13 (1980).

5. Brooke, O. G. and Ashworth, A.: The influence of malnutrition on postprandial metabolic rate and respiratory quotient. Br. J. Nutr., 27: 407 (1972).

6. Brooke, O. G., Alvear, J., and Arnold, M.: Energy retention, energy expenditure and growth in healthy immature infants. Pediatr. Res., 13:215 (1979).

7. Brück, K.: Temperature regulation in the newborn infant. Biol. Neonate, 3: 65 (1961).

8. Chessex, P., Reichman, B. L., Verellen, G. J. E., Putet, G., Smith, J. M., Heim, T., and Swyer, P. R.: Energy cost of growth of very low birth weight infants. Pediatr. Res., 15: 478 (1981).

9. Chessex, P., Reichman, B. L., Verellen, G. J. E., Putet, G., Smith, J. M., Heim, T., and Swyer, P. R.: Influence of postnatal age energy intake and weight gain on energy metabolism in the very low-birth weight infant. J. Pediatr., 99: 761 (1981)

10. Gentz, J., Kellum, M., and Persson, B.: The effect of feeding on oxygen consumption RQ and plasma levels of glucose, FFA and D- $\beta$ hydroxybutyrate in newborn infants of diabetic mothers and small for gestational age infants. Acta Pediatr. Scand. 65: 445 (1976).

11. Gordon, M. H., Levine, S. Z., Deamer, W. C., and McNamara, M.: Respiratory metabolism in infancy and in childhood XXIII. Am. J. Dis. Child., 59: 1185 (1940).

12. Hey, E. N.: The relation between environmental temperature and oxygen consumption in the newborn baby. J. Physiol. (London), 200: 589 (1969).

13. Hey, E. N. and Katz, G.: The optimum thermal environment for naked babies. Arch. Dis. Child., 45: 328 (1970).

14. Hommes, F. A., Drost, Y. M., Geraerts, W. X. M., and Reyenga, M. A. A.: The energy requirements for growth; an application of Atkinson's metabolic price system. Pediatr. Res., 9: 51 (1975).

15. Hommes, F. A.: The energy requirements for growth. A reevaluation. Nutr. Metab., 24: 110 (1980).

16. Kraus, A. N. and Auld, P. A. M.: Metabolic requirements of low birth weight infants. J. Pediatr., 75: 952 (1969).

17. Mestyan, J., Fekete, M., Bata, G., and Jarai, I.: The basal metabolic rate of premature infants. Biol. Neonate, 7: 11 (1964).

18. Micheli, J., Gudinchet, F., Stettler, E., Schutz, Y., and Jequier, E.: Relationship between energy expenditure and weight gain in very low birth weight infants during the first week of life. Pediatr. Res., 14:1421 (1980).

19. Prechtl, H. F. R.: The behavioral states of the newborn infant (a review). Brain Res., 76: 185 (1974)

20. Reichman, B. L., Chessex, P., Putet, G., Verellen, G. J. E., Smith, J. M., Heim, T., and Swyer, P. R.: Partition of energy metabolism in the very low birth weight infant. Pediatr. Res., 15: 677 (1981).

21. Roy, C. C., Ste. Marie, M., Chartrand, L., Weber, A., Bard, H., and Doray, B. Correction of the malabsorption of the preterm infant with a medium chain triglyceride formula. J. Pediatr., 86: 446 (1975).

22. Rubecz, I. and Mestyan, J.: The partition of maintenance energy expenditure and the pattern of substrate utilization in uterine malnourished newborn infants before and during recovery. Acta Pediatr. Acad. Sci. Hung., 16: 335 (1975).

23. Rutter, N., Brown, S. M., and Hull, D.: Variations in the resting oxygen consumption of small babies. Arch. Dis. Child., 53: 850 (1978).

24. Sauer, P. J. J., Pearse, R. G., Dane, H. J., and Visser, H. K. A.: The energy cost of growth estimated from simultaneous direct and indirect calorimetry in infants of less than 2,500 g. In: H. K. A. Visser: Nutrition and Metabolism of the Fetus and Infant. pp. 93-107 (Martinus Nijhoff Publishers BV, The Hague 1979).

25. Scopes; J. W. and Ahmed, I.: Minimal rates of oxygen consumption in sick and premature newborn infants. Arch. Dis. Child., $41: 407$ (1966). 
26. Shenai, J. P., Reynolds, J. W., and Babson, S. G.: Nutritional balance studies in very low birth weight infants: enhanced nutrient retention by an experimental formula. Pediatrics, 66: 233 (1980).

27. Sinclair, J. C.: Energy balance in the newborn. In J. C. Sinclair: Temperature Regulation and Energy Metabolism in the Newborn. pp. 187-204 (Grune and Stratton, New York 1978).

28. Sinclair, J. C. and Silverman, A.: Longitudinal measurements of oxygen consumption and heat flux in low birth weight infants. Meeting of the American Pediatric Society and the Society for Pediatric Research 1970, p. 246.

29. Spady, J. W., Payne, P. R., Picou, D., and Waterlow, J. C.: Energy balance during recovery from malnutrition. Am. J. Clin. Nutr., 29: 1073 (1976).

30. Stewart, A. L., Reynolds, E. O. R., and Lipscomb, A. P.: Outcome for infants of very low birthweight; survey of world literature. Lancet, 1 : 1038 (1981).
31. Tantibhedhyangkul, P. and Hashim, S. A.: Medium chain triglyceride feeding in premature infants; effects on fat and nitrogen absorption. Pediatrics, 55 : 359 (1975).

32. Usher, R. and McLean, F.: Intrauterine growth of live born caucasian infants at sea level; standards obtained from measurements in 7 dimensions of infants born between 25 and 44 weeks gestation. J. Pediatr., 74: 901 (1969).

33. Ziegler, E. E., O'Donnell, A. M., Nelson, S. E., and Fomon, S. J.: Body composition of the reference fetus. Growth, 40: 329 (1976).

34. Requests for reprints should be addressed to: Dr. P. J. J. Sauer, Division of Neonatology and Nutrition, The Hospital for Sick Children, 555 University Avenue, Toronto, Ontario Canada M5G 1 X8.

35. Received for publication June 3,1982.

36. Accepted for publication September 11, 1983.

\title{
Congenital Expression of Prolidase Defect in Prolidase Deficiency
}

\author{
EILEEN R. NAUGHTEN, ${ }^{(24)}$ SUSAN P. PROCTOR, ${ }^{(25)}$ HARVEY L. LEVY, ${ }^{(27)}$ \\ J. THOMAS COULOMBE, AND MARY G. AMPOLA \\ Joseph P. Kennedy Jr. Laboratories of the Neurology Service, Massachusetts General Hospital and the \\ Department of Neurology, Harvard Medical School; the State Laboratory Institute, Massachusetts Department of \\ Public Health; and the Amino Acid Laboratory, Tufts-New England Medical Center, \\ Boston, Massachusetts, USA
}

\section{Summary}

Newborn blood from three siblings with prolidase deficiency contained no detectable prolidase activity. Umbilical cord blood contained no prolidase activity in one sibling and only $6.8 \%$ of control activity in another sibling. In prolidase deficiency the enzyme defect is expressed at birth, well before the appearance of skin ulcers, and is demonstrable in filter paper specimens of blood obtained for routine screening.

Some genetic disorders are not clinically recognizable at birth or even during the first years of life. Unless a biochemical marker or other mutant gene product is recognized at or near birth, the congenital nature of the disorder is unproven. Examples of this include Huntington's Disease (2), Wilson's Disease (4), and Marfan's Syndrome (17). When a marker is identifiable, as in phenylketonuria (20), the disease is recognized as congenital.

Prolidase deficiency is a biochemical disorder that is inherited as an autosomal recessive trait. The disorder is characterized by severe skin ulcers that generally develop during childhood or adolescence. Reduced intelligence has also been observed in some patients. When brought to medical attention, affected individuals have iminodipeptiduria and a deficiency of prolidase activity ( 3 , $6,10,15,21)$. No patient has yet been studied at birth or shortly thereafter to determine whether the biochemical defect is indeed congenital.

We have examined prolidase activity in specimens of umbilical cord blood and newborn blood from three siblings with prolidase deficiency. Our results demonstrate that prolidase deficiency is biochemically expressed at birth; thus, prolidase deficiency can be detected by appropriate testing at birth and, most likely, could also be identified in the fetus through prenatal studies.

\section{MATERIALS AND METHODS}

Newborn blood specimens and patients. Filter paper specimens of dried blood that were used for routine newborn screening (13) and that were stored in envelops at room temperature were recovered. The samples included umbilical cord blood and newborn blood from two siblings with prolidase deficiency and newborn blood from a third sibling. Control umbilical cord and newborn blood specimens age-matched for each patient were also recovered from storage. The family came to attention when glycylprolinuria was detected by routine newborn urine screening in the youngest sibling (14). The two brothers, ages 3 and $4 \mathrm{yr}$, have mild developmental delay. The proband, a 19-mo-old girl, has mild hypotonia. The children are otherwise asymptomatic. All three have marked iminodipeptiduria and reduced erythrocyte prolidase activity (approximately $10 \%$ of normal).

Prolidase and prolinase assays. Prolidase (EC 3.4.3.7) is an iminodipeptidase which splits iminopeptides with C-terminal proline or hydroxyproline. It is most active with glycyl-L-proline, which is cleaved to glycine and L-proline (9). We measured prolidase activity by a modification of the method of Endo and Matsuda (8). Discs $3 / 16$ inch in diameter were punched from each specimen and the blood was eluted at $4^{\circ} \mathrm{C}$ in a solution containing $0.250 \mathrm{ml}$ of $0.1 \mathrm{M}$ Tris- $\mathrm{HCl}$ buffer, $\mathrm{pH} 8.0$, and $0.006 \mathrm{ml}$ of 0.01 $\mathrm{M} \mathrm{MnCl}$. The duration of elution varied with the age of the specimen. The specimens stored for 9 mo were eluted for $24 \mathrm{~h}$. With this elution time, however, enzyme activity was not detectable in eluates from control specimens stored for 3 and 4 yr, so elution with these and patient samples was continued for $1 \mathrm{wk}$. The eluates were preincubated at $37^{\circ} \mathrm{C}$ for $1 \mathrm{~h}$ after which 0.05 $\mathrm{ml}$ of $12 \mathrm{mM}$ glycyl-L-proline (made up in $0.1 \mathrm{M}$ Tris- $\mathrm{HCl}$ buffer, $\mathrm{pH} 8.0$ ) was added. The volume of the final reaction mixture was $0.306 \mathrm{ml}$ containing $0.196 \mathrm{mM} \mathrm{MnCl}_{2}$ and 1.96 